University of Nebraska - Lincoln

DigitalCommons@University of Nebraska - Lincoln

Publications from USDA-ARS / UNL Faculty

U.S. Department of Agriculture: Agricultural

Research Service, Lincoln, Nebraska

2005

Renovating Pastures with Glyphosate Tolerant Soybeans

\author{
Robert B. Mitchell \\ University of Nebraska-Lincoln, rob.mitchell@ars.usda.gov \\ Kenneth P. Vogel \\ University of Nebraska-Lincoln, kvogel1@unl.edu \\ Bruce Anderson \\ University of Nebraska-Lincoln, banderson1@unl.edu \\ T. J. McAndrew \\ University of Nebraska-Lincoln, tmcandrew2@unl.edu
}

Follow this and additional works at: https://digitalcommons.unl.edu/usdaarsfacpub

Mitchell, Robert B.; Vogel, Kenneth P.; Anderson, Bruce; and McAndrew, T. J., "Renovating Pastures with Glyphosate Tolerant Soybeans" (2005). Publications from USDA-ARS / UNL Faculty. 1925.

https://digitalcommons.unl.edu/usdaarsfacpub/1925

This Article is brought to you for free and open access by the U.S. Department of Agriculture: Agricultural Research Service, Lincoln, Nebraska at DigitalCommons@University of Nebraska - Lincoln. It has been accepted for inclusion in Publications from USDA-ARS / UNL Faculty by an authorized administrator of DigitalCommons@University of Nebraska - Lincoln. 
(c) 2005 Plant Management Network. This article is in the public domain.

Accepted for publication 13 April 2005. Published 28 April 2005.

\section{Renovating Pastures with Glyphosate Tolerant Soybeans}

Rob Mitchell and Ken Vogel, USDA-ARS, Department of Agronomy and Horticulture, University of Nebraska, Lincoln 68583; Bruce Anderson and T. J. McAndrew, Department of Agronomy and Horticulture, University of Nebraska, Lincoln 68583

Corresponding author: Rob Mitchell. rmitchell4@unl.edu

Mitchell, R., Vogel, K., Anderson, B., and McAndrew, T. J. 2005. Renovating pastures with glyphosate tolerant soybeans. Online. Forage and Grazinglands doi: 10.1094/FG-20050428-01-BR.

Pasture renovation is expensive because of lost production, costs for eliminating existing vegetation by tillage or herbicides, and direct replanting costs. Reducing costs, reducing risk of failure, and producing income from pasture land during renovation can significantly increase the profitability of improving pastures.

Technology developed for soybean production can be used to renovate pasture. Roundup Ready (glyphosate-resistant) technology can be used to eliminate existing vegetation, produce income from soybeans during renovation, and prepare a good seedbed for replanting areas to forages.

The goal of pasture renovation is to replace plants that do not fit your needs with forages better suited to your pasture needs. The first step is to eliminate undesirable plants with tillage or herbicides. Herbicides can significantly reduce producer's energy input costs and soil erosion. Planting a glyphosate-tolerant soybean crop enables the use of glyphosate for weed control. This process maintains pasture residue on site, reduces soil erosion and desiccation, and produces income during renovation. Soybeans are preferable to corn because soybeans provide residual nitrogen, produce an excellent seedbed for no-till planting, and leave sufficient residue to protect the soil without interfering with seeding.

We conduct grazing research and regularly use glyphosate-tolerant soybeans to replace research pastures and forage research fields. Based on our experience, we have developed some guidelines for successfully using glyphosate-tolerant soybeans for pasture renovation.

- Remove pasture residue by haying, grazing, or burning before soybean planting. This increases grazing days or produces hay, reduces competition for the soybean crop, and may reduce the amount of glyphosate required.

- No-till plant soybean and spray glyphosate at 2 qt/ acre 3 to 6 weeks after planting, depending on pasture growth rate. Pasture regrowth should be about 4 inches tall when glyphosate is sprayed. If undesirable plants are present later in the growing season, follow recommendations for controlling weeds in glyphosate-tolerant soybeans.

- If plants from the previous pasture are still present after soybean harvest, a late summer or autumn application of 1 to 2 qt of glyphosate will prepare the pasture for planting. The maximum allowable application quantity per year for Roundup Original is 8 $\mathrm{qt} / \mathrm{acre}$.

- No-till seed desired grasses and legumes during the next available recommended planting period. 
-To plant perennial cool-season grasses and legumes in late summer after soybean harvest, plant the earliest-maturing soybean variety adapted to your area, and harvest the crop as soon as possible, maybe as hay or pasture instead of grain. Plant coolseason forages immediately after harvest to maximize the number of growing days before winter. If late-summer planting cannot be completed during the recommended dates for cool-season species in your area, wait until early spring to plant. Planting the following spring will provide the best opportunity for a successful stand of warm-season grasses. Avoid seeding warm-season grasses in late summer or autumn because they may not survive winter.

-When cool- or warm-season forages are to be planted during the spring following soybean harvest, plant a full-season soybean cultivar to maximize soybean yield and competition with weeds. If weeds are present prior to grass planting, spray a recommended herbicide before no-till planting.

This approach provides income during pasture renovation. In pastures and fields renovated in 2004 near Omaha, NE, soybean yields were 30 to $40 \mathrm{bu} /$ acre (Fig. 1). Additionally, it prepares an excellent weed-free seedbed for grass establishment, and no-till seeding forages into soybean stubble reduces tillage and weed control costs during establishment. Growing soybeans for 2 years will control noxious weeds from the previous pasture.

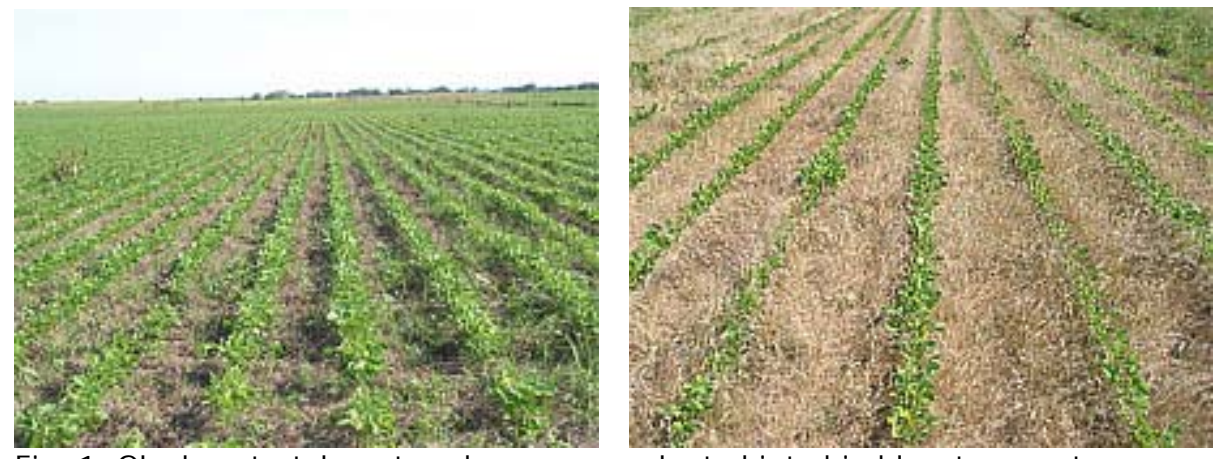

Fig. 1. Glyphosate-tolerant soybeans were planted into big bluestem pasture (left) and tall fescue and Kentucky bluegrass mixtures (right). Both were sprayed with glyphosate after soybean emergence, and produced soybeans at 30 to 40 bu/acre.

Good grazing, fertility, and weed management will optimize the productive potential and life-span of new pastures. Using glyphosate-tolerant technology can reduce pasture renovation costs and increase the probability of success for pasture re-establishment.

\section{Disclaimer}

Mention of trade names or commercial products in this publication is solely for the purpose of providing specific information and does not imply recommendation or endorsement by the U.S. Department of Agriculture or the University of Nebraska. 